\title{
Green Central Banking
}

Peter Dietsch, University of Victoria

Clément Fontan, UCLouvain and USL-B

Jérémie Dion, Université du Québec à Montréal

François Claveau, Université de Sherbrooke

\begin{abstract}
This chapter argues that central banks find themselves between a rock and a hard place when it comes to green central banking. Either they endorse the project, exposing them to the charge that they lack the input legitimacy to do so, or they eschew taking into account climate concerns, thus undermining their output legitimacy. Our discourse analysis of central bankers's speeches shows that disagreements among officials from the same institution regarding green central banking are grounded on issues outside their core expertise. Furthermore, neither the conservative nor the progressive central bankers defend positions that have the potential to overcome the legitimacy dilemma we formulate.
\end{abstract}

Keywords. Monetary policy, Central banking, Climate change, Climate finance, Political legitimacy, Computer-assisted discourse analysis

Chapter forthcoming in Sandberg, J. \& Warenski, L. (eds). The Philosophy of Money and Finance, Oxford, UK:

Oxford University Press.

Corresponding author: Clément Fontan < $\underline{\text { clement.fontan@uclouvain.be> }}$ 


\section{Introduction}

In response to the global financial crisis, central banks grew into what experts have dubbed "the only game in town" in macroeconomic policy (El-Erian, 2017). The policy response to COVID-19 has cemented further the key role that monetary policy plays in our economies today. Moreover, calls have grown louder in recent years for central banks not only to do their traditional job of ensuring price stability and financial stability, but also to keep an eye on other policy objectives. Notably, there is growing public pressure for central bankers to promote the transition to a lowcarbon economy with their monetary policy tools. For example, in March 2021, Greenpeace activists paraglided onto the European Central Bank (ECB)'s roof to denounce the fact that its monetary policy helps to fund fossil fuel companies. ${ }^{1}$

Should central bankers promote the transition to a low-carbon economy? The contribution of this paper lies in formulating an answer to this question from the perspective of legitimacy. To wit, can independent central banks justify employing their monetary policy tools in the name of "green central banking" and, if so, under what conditions?

Our argument proceeds in three steps. First, we explain what we mean both by green central banking and by the concept of legitimacy that we use as a normative benchmark. More specifically, we focus on monetary policy measures that not only incorporate climate change concerns when they pose a risk to the core central bank mandate of price stability, but ones that take seriously potential trade-offs with other policy objectives. Furthermore, we show that central banks face a dilemma between violating norms of either "input legitimacy" or "output legitimacy" when it comes to green central banking.

Second, we analyze where the monetary policy experts themselves stand on the issue thanks to a computer-assisted discourse analysis of 17,105 speeches from central bankers around the world. We show that there is a significant amount of disagreement among them about whether they should

1 Johanna Treeck, "Greenpeace lands on ECB tower in climate finance protest", Politico, accessed on October 29th, 2021, https://www.politico.eu/article/greenpeace-protest-european-central-bank-paraglider-climate-financecarbon/ 
actively promote the transition to a low-carbon economy. Interestingly, the positions we find in the central banking community today fail to overcome the dilemma identified in the previous section.

The final section of the paper points to ways in which the dilemma could in fact be overcome. In other words, it spells out the conditions that need to be met for a central bank to legitimately deploy monetary policy tools that impact the transition to a low-carbon economy. In a nutshell, the most promising way for central banks to balance the demands of input and output legitimacy is to coordinate their policies with elected officials.

\section{Green central banking: monetary policy and political legitimacy}

\subsection{Using monetary policy as a greening technology}

Before addressing the issue of whether central banks should be sensitive to environmental concerns in their decision-making, and how doing or not doing so affects their legitimacy, we explore in this section the various ways in which central banks can show such sensitivity. In other words, we provide the conceptual background against which the debate on the legitimacy of green central banking takes place.

Similar to central bankers' discourse (see next section), theoretical work on this issue has been evolving rapidly in recent years (e.g. Baer et al. 2021; Bolton et al. 2020; Campiglio et al. 2018; D’Orazio and Popoyan 2020; Barmes and Livingstone 2021; Monnin 2018; Dikau and RyanCollins 2017; Volz 2017). ${ }^{2}$ For the purposes of this chapter, we rely on the classification developed by Baer et al. (2021), which characterizes central bank actions along three dimensions.

First, Baer and co-authors distinguish between prudential and promotional motives central banks might have to intervene (ibid: :2-3). Whereas prudential motives refer to the mitigation of risks to the traditional mandate of central banks - e.g. the risks climate change poses to financial or price stability - when a central bank acts with policy objectives outside its traditional mandate in mind

\footnotetext{
2 More than half of the sixty-odd articles on Scopus mentioning both "central banks" and "climate change" have appeared since 2020 .
} 
- in the present case, furthering the transition towards a low-carbon economy ${ }^{3}$ - it acts for promotional motives. Our paper focuses on the latter. According to many researchers, the enormous potential of using the social technology of money creation to promote the green transition is obvious (cf. Ingham 2020; Hockett and James 2020). However, acting on such promotional motives is where the primary challenge to the legitimacy of independent central banks lies. ${ }^{4}$

Second, Baer and co-authors list three types of measures that central banks can take to pursue their prudential or promotional policy objectives, including the transition to a low-carbon economy: they can ensure the availability of information on markets, for instance by requiring commercial banks to disclose the climate-related risks on their books; they can incentivize commercial banks to adopt certain kinds of behaviour, for example "by including [climate-related risks] in the evaluation of asset eligibility as part of collateral frameworks or asset purchase programs" (Baer et al. 2021: 3); finally, they can impose quotas on certain financial flows through sectoral credit targets and the like. For our paper, the distinction between these three types is secondary. While more coercive measures, such as quotas, perhaps tend to raise more forceful challenges to legitimacy, the fact that they do so ultimately stems from their promotional character.

Third, Baer and co-authors emphasize that the actions of delegated agencies such as central banks have to be assessed in conjunction with the actions of political agencies. In other words, a comprehensive look at the actions of the agent - the central bank - also requires an eye on the actions of the principal - the governments and parliaments that formulate the central bank's mandate (Elgie 2002).

In the present context, this distinction between delegated and political agencies has an important consequence for legitimacy. From a normative perspective, actual mandates are secondary. What matters is what should be in the mandate or, more generally, how the division of labour between government and central bank should be structured. Put differently, an evaluation of the legitimacy of central banks based on current mandates and practices would be shortsighted. Instead, such an

\footnotetext{
${ }^{3}$ Similar arguments could be developed for other aspects of environmental policy, such as for instance the protection of biodiversity. For reasons of space, we focus on the transition towards a low-carbon economy here.

${ }^{4}$ Note, however, that legitimacy challenges can also arise from unintentional consequences that central bank actions on goals contained in their mandate - e.g. price stability - might have on policy objectives outside their mandate - e.g. inequality or climate change. We have focused on these unintentional consequences in previous work (e.g. Fontan et al. 2016).
} 
evaluation can only be done as part of an evaluation of the overall institutional structure that central banks form a part of, and of the social objectives pursued by the latter. We shall come back to this issue in section 4.

\subsection{The legitimacy of green central banking}

What is the criterion to assess the legitimacy of a public institution? ${ }^{5}$ Legitimacy hinges on the capacity to provide a justification for the coercive political power exercised over citizens (cf. Peter 2017; see also Buchanan 2002; Peter 2009). In societies that aim at some form of collective selfdetermination, such justifications typically take two basic forms (Scharpf 1997). First, political decisions should be derived, directly or not, from the preferences of citizens. Second, political decisions should be effective at "achieving the goals, and avoiding the dangers, that citizens collectively care about." (Scharpf 1997, 19) In the political science literature, "input legitimacy" and "output legitimacy" respectively have been used to label these two kinds of justification (Scharpf 1997, Steffek 2019).

A dominant view today is that some institutional configurations are more effective at delivering what citizens want by partially removing the influence of elected representatives on political decisions. The creation of more and more independent agencies that make policy at arm's length from parliament is a symptom of this increasing emphasis on output legitimacy (Majone 1996; OECD 2002). ${ }^{6}$ The operational independence of central banks is one paradigmatic example for such independent agencies. According to the 'Central Bank Independence' (CBI) template, which was widely implemented in the 1990s, central banks should be granted operational independence while operating within a narrow mandate (see also Dietsch et al., 2018, chapter 1). Nominations and some accountability procedures, such as parliamentary hearings, are in place to ensure that central banks do not fray too far from the preferences of citizens, but this infusion of input legitimacy happens only sporadically.

\footnotetext{
${ }^{5}$ The section is in part informed by Dietsch (2020).

${ }^{6}$ At the theoretical level, an example of this emphasis on output legitimacy is the instrumentalist case for democracy, which assesses democracy through a consequentialist lens while not according weight to the procedural values of democracy (e.g. Arneson 2003; Brennan 2016; for a critical discussion see Viehoff, unpublished).
} 
According to the same dominant view, some decisions, namely those with distributive consequences, should be made by elected representatives (e.g., Tucker 2018). Citizens are likely to disagree on who should gain and lose from these political decisions. It is thus considered more input legitimate to leave them to policymakers who have a direct democratic mandate, even if that might mean less effectiveness. This explains why the idea of distributive neutrality is tightly associated to contemporary central banks and other macroeconomic regulatory institutions. According to central bankers themselves, their high level of independence does not allow them to favor one economic player or sector over another (Issing et al. 2001). This is why the CBI template prescribes a strict division of labor between central bankers and government: the former should only aim at price stability, while the latter should take monetary policy as a given and adjust its budgetary and fiscal policies to address potential distributive concerns.

When a public institution either acquires new competences or, by virtue of adjusting the policy tools used to fulfill its traditional role, finds itself in a situation where its policies create trade-offs with other important societal goals, its legitimacy needs to be reassessed. ${ }^{7}$ Central banks find themselves in this situation today. The prospect of green central banking confronts them with a dilemma that can be expressed as a tension between input versus output legitimacy.

On the one hand, citizens clearly want to avoid extreme climate change. They demand that political institutions deliver on international climate pledges. Hence, even though environmental goals are usually not part of central bank mandates today, pursuing policies that might undermine such goals is deemed unacceptable in an era dominated by climate change as the single most important threat to humanity. If central bank actions lack sensitivity to climate change, this undermines their output legitimacy. In fact, climate insensitive central banks could be perceived as part of the problem by the public at large or by elected officials who could score political points by threatening to remove central bankers. ${ }^{8}$

\footnotetext{
${ }^{7}$ For the case that regular reassessment should be a constitutive part of any delegation to an independent agency in a democracy to begin with, see Downey (2021).

${ }^{8}$ See, e.g., US democrats using this strategy (Thomas, August 31 ${ }^{\text {st }}, 2021$, https://www.bbc.com/news/business58400767 ). Polls conducted by the NGFS (2019) showed that reputational concerns were the first motivation for the integration of Socially Responsible Investment guidelines within central banks.
} 
On the other hand, environmental policies come with strong distributional consequences. Climate policies generate winners and losers, and there is no consensus on who should bear the burden. Citizens should thus have relatively direct control on the political institutions fighting climate change. Hence, from the perspective of input legitimacy, independent central banks should not take climate decisions.

In the next section, we examine how central bankers themselves view the effect that adopting green policies of various types might have on their legitimacy. For reasons of space, both the discourse analysis of section 3 and the evaluation of legitimacy in section 4 will focus on monetary policy as opposed to some of the other regulatory roles played by central banks such as financial supervision. For instance, we will focus on promotional monetary policy tools such as green asset purchase programs and collateral frameworks rather than supervisory policies such as green capital requirements.

\section{Green central banking: a discourse analysis}

The computer-assisted discourse analysis in this section is based on 17,105 speeches from central bankers around the world. Our method allows us to retrieve the few relevant segments in this large corpus, which are then interpreted manually. The methodological details of our analysis as well as our corpus are available in a web appendix. ${ }^{9}$

We show that central bankers in South-East Asia were the first to discuss and implement green monetary policy, without much controversy since it was in line with their focus on economic development. By contrast, we shall see that Western independent central banks were slower to agree on a consensual set of theoretical principles. We end our discursive analysis by outlining a number of disagreements among European central bankers on whether they can legitimately implement measures to promote the transition to a low-carbon economy. These disagreements nicely illustrate the dilemma identified in section 2 that central banks face when it comes to green central banking.

\footnotetext{
${ }^{9}$ The web appendix on Zenodo: https://zenodo.org/record/5998034. These speeches are also available on the website of the Bank for International Settlements: https://www.bis.org/cbspeeches/ (last accessed: 2021-10-24).
} 


\subsection{It started in South-East Asia: the road to climate awareness}

Central bankers have developed an interest in climate issues only recently, when they realized that climate change could negatively affect their policy objectives such as price or financial stability. The consensual position used to be that the best way for them to contribute to societal efforts to implement a low-carbon economy was to remain focused on their narrow price stability objective. Jean-Claude Trichet, the ECB chairperson from 2003 to 2011, expressed this consensus in 2008:

The [price stability] task is complicated by interaction with the other factors - for example, by the impact of global resource constraints or the growing concerns about climate change - but monetary policy stays firmly focused on delivering price stability, which is important for the efficient working of the market system and the optimal allocation of resources. ${ }^{10}$

However, this position started to evolve in South-East Asia in the aftermath of the global financial crisis. In the majority of countries in that region, central banks have long been either playing a "developmental role," in which they implement their monetary and prudential tools to target economic sectors and objectives prioritized by their governments, or working in close collaboration with governmental agencies (Volz 2017). From this perspective, adding new green objectives to the central bank purview is in line with their regular mode of operations and does not create new legitimacy dilemmas, because the decisions in question are validated with officials benefiting from some form of input legitimacy.

Figure 1: The global evolution of central banks discourse on climate change

${ }^{10}$ Trichet, 3 June 2008. 


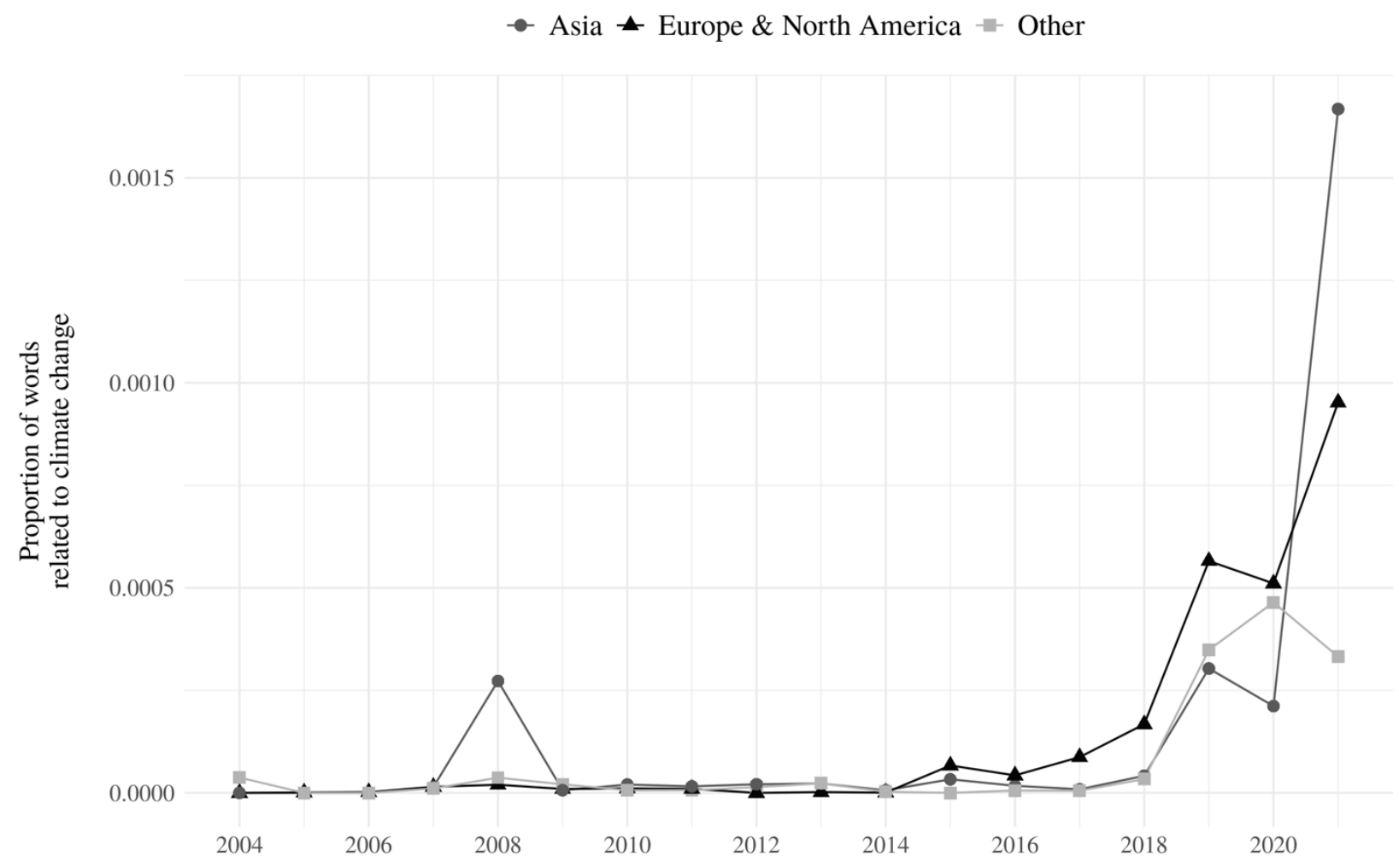

Sources: https://www.bis.org/cbspeeches/

For example, Boediono, the governor of Bank Indonesia between 2008 and 2009, stated that during the 2007 UN Climate Change Conference in Bali "187 nations [...] acknowledged the unequivocal evidence of global warming and risks of severe climate change impacts." ${ }^{11}$ In connection with these political goals, the governor underlined that "to properly define our role, $[\ldots]$ we need to spell out as precisely as we can the ramification of the macroeconomic impact of global climate change." 12 In other words, Bank Indonesia was at the vanguard of adopting promotional policy objectives with informational tools. In turn, other central banks, such as the Bank of Bangladesh and the People's Bank of China (PBOC) implemented similar measures and went even further as they were the first to implement credit refinancing lines at favorable terms for green activities as well as quotas for lending to carbon-intensive sectors (Dikau and Ryan Collins 2017). In other words, they

\footnotetext{
${ }^{11}$ Boediono, 1-2 August 2008.

${ }^{12}$ Boediono, 1-2 August 2008.
} 
added incentives and quotas to the arsenal of promotional tools employed by central banks in South-East Asia.

\subsection{The consensus view in the Western world}

In the Western world, awareness of the links between climate change and central banking was slower to materialize. A 2015 speech by the then governor of the Bank of England Mark Carney on "breaking the tragedy of the horizon" is usually considered the starting point of the "green turn" among Western central bankers. In this speech, Carney outlined two risks faced by central banks: physical risks (i.e., the material damages related to climate change on economic systems) and transition risks (i.e., the impact of the race towards net zero objectives on firms with a heavy carbon footprint). While Carney warned about the urgency to act on these risks, the responsibilities he saw as lying with delegated agencies were minimal:

Financial policymakers will not drive the transition to a low-carbon economy. [...] But the risks that I have outlined mean financial policymakers do, however, have a clear interest in ensuring the financial system is resilient to any transition [...] [. O]ur role can be in developing the frameworks that help the market itself to adjust efficiently. ${ }^{13}$

This speech was influential for other independent central bankers to define a minimal consensus view on green central banking, which sets both lower and upper bounds to central bank involvement in the transition.

Regarding the lower bounds of the consensus, even central bankers who are staunch defenders of the narrow CBI template recognize the links between climate risks and their policy objectives. For instance, Jens Weidmann, who was at the helm of the German central bank from 2011 to 2021, grants that "[c]limate change, in particular, is one of the most pressing challenges of our times. All public and private institutions should therefore take action within their respective mandate to tackle them." ${ }^{14}$ Representatives from the Federal Reserve and the Bank of Canada, both laggards in the implementation of green measures, accept that it is important for them to "study the implications of climate change for the economy and the financial system and to adapt our work accordingly." 15

\footnotetext{
${ }^{13}$ Carney, 29 September 2015.

14 Weidmann, 3 February 2020.

15 Brainard, 8 November 2019. See also Lane, 2 March 2017.
} 
In other words, today, the debate on whether central banks should consider climate change for prudential motives with informational tools is settled. Even the most reluctant central bankers agree with this minimal commitment.

Turning to the upper bounds of the consensus, central bankers who are advocates of green central banking, such as Isabel Schnabel or Frank Elderson, the two newest members of the board of the ECB, recognize two kinds of limits to their commitment. First, Schnabel grants that monetary policy follows an inherently cyclical logic, which is ill suited to the structural challenge of climate change. ${ }^{16}$ On this point, Schnabel echoes the analysis of Weidmann, who otherwise holds opposite views on the desirability of green central banking: "Ultimately, monetary policy is not a structural policy instrument: it is cyclical in nature." ${ }^{17}$ Second, in line with the first point and with Carney's speech, central bankers highlight that they should eschew policy trade-offs with their regular policy objectives, notably with price stability. ${ }^{18}$ Moreover, they emphasize that they should also respect their mandates. In the case of the ECB, the mandate includes "the principles of proportionality and an 'open market economy'."19

The policy upshot of these limits is that central banks should only play a subordinated role to governments when it comes to climate change. For example, even though the Bank of England has implemented many green measures since the speech of Carney in $2015,{ }^{20}$ its current governor repeats Carney's arguments about the division of labor between delegated and political agencies: "We are not here to 'solve' climate change or drive the transition. Those with the mandate and the tools to lead this fight sit elsewhere." 21 Other Western central bankers who claim that they are committed to fight climate change, such as the Finnish central bank, rehearse the same argument: "Central banks should not be the primary actors in mitigating climate change and reducing biodiversity loss." 22

\footnotetext{
${ }^{16}$ Schnabel, 3 March 2021.

17 Weidmann, 1 July 2021.

18 Coeuré, 8 November 2018.

19 Schnabel, 3 March 2021.

20 See the dedicated page on the Bank's website: https://www.bankofengland.co.uk/climate-change (last accessed: 2021-11-01)

${ }^{21}$ Bailey, 1 June 2021.

22 Nykänen, 21 May 2021.
} 
These consensual views take direct cues from the CBI template and can be interpreted in terms of the balance between input and output legitimacy (cf. section 2). Central banks have the toolbox and the mandate to care primarily about price stability, where they consider their output legitimacy to lie. ${ }^{23}$ By contrast, governments have the toolbox and the input legitimacy to be the primary drivers of the transition to a low-carbon economy, for which many decisions will have distributive consequences that are too important to be left to an independent public institution. Incidentally, note that central bankers rely on a parallel argument when it comes to defending their massive asset purchases in recent years against the charge that they have an unintended exacerbating effect on inequality (Fontan et al., 2016; Dietsch et al., 2018).

\subsection{Divergent interpretations of the mandate and the menu of policy options}

Contrary to issues pertaining to economic inequalities, the gloss of consensus among central bankers on green central banking - adopt prudential measures, leave the driver seat to elected decision makers, and avoid measures that entail trade-offs with price and financial stability quickly fades away when it comes to concrete policy implications. Today, central bankers support different green policy options, depending on how they interpret their mandate and the balance of threats to their input and output legitimacies. In this section, we rely on the case of the Eurosystem ${ }^{24}$ to show that, even when central bankers have the same mandate, they can interpret it in different ways and, accordingly, advocate for a more or less active role in fighting climate change.

On the one hand, the Eurosystem members who would like to return to a narrow model of central banking underline that they do not have the mandate and the input legitimacy to go beyond policies backed by prudential motives.

We can use our expertise to conduct research and analysis to deepen our understanding of how climate change will affect both the financial system and economies. However,

\footnotetext{
${ }^{23}$ As already mentioned in section 2, this narrow construal of their output legitimacy is problematic, as the output legitimacy of public institutions needs to be evaluated as a whole. We shall come back to this point in section 4.

${ }^{24}$ On the different stances and alliances within the Eurosystem, see (Ferrara 2019).
} 
it is clear that central banks do not have a mandate to address the causes of climate change or the transition to a low-carbon economy itself. ${ }^{25}$

These central bankers put forward three justifications for the interpretation of their mandate and legitimacy. First, they underline that playing an active greening role would push them onto the field of distributive politics:

Climate change poses the risk of considerable social costs and economic disruption. The challenges of climate change are social issues. The analysis and choice of possible solutions, including suitable instruments and their financing, require rigorous political debate. And no matter which path a society takes, the potential changes can have serious effects on sectors, regions, the distribution of income and wealth, and generations over time. Economically, there will be relative winners and losers. It is therefore the responsibility of elected representatives to decide on the best solutions. ${ }^{26}$

Second, they argue that some potential greening measures, such as removing securities of fossil fuel companies from the ECB asset purchase programmes, would undermine the principle of market neutrality: "We have to make sure that we are not creating market distortions, of course we have to remain market-neutral." 27

Third, they insist that, even if their lack of input legitimacy was mitigated by an official delegation of new policy objectives, these new objectives could lead to efficiency losses and mission creep and, ultimately, to the loss of independence:

A monetary policy which pursues explicitly environmental policy objectives is at risk of being overburdened. And in the long run, the central bank's independence might be called into question. ${ }^{28}$

On the other hand, Eurosystem central bankers who support a wider model of central banking tend to interpret the ECB mandate in a more flexible way and as supporting both incentive-based and quota-based promotional policy measures. For example, Isabel Schnabel ${ }^{29}$ and Frank Elderson ${ }^{30}$

\footnotetext{
25 Donnery, 31 January 2020. See also Mersch, 27 November 2018.

26 idem. See also: Weidmann, 29 October 2019; Weidmann, 1 July 2021.

27 Lautenschläger, 30 October 2019. See also: Mersch, 27 November 2018.

28 Weidmann, 29 October 2019. See also: Maechler and Moser, 14 November 2019; Mersch, 27 November 2018 ; Weidmann, 1 July 2021.

${ }^{29}$ Schnabel, 27 May 2021.

30 See Elderson's argument published on the ECB blog:

https://www.ecb.europa.eu/press/blog/date/2021/html/ecb.blog210213 7e26af8606.en.html
} 
argue that the ECB primary mandate requires it to consider climate change, while its secondary mandate, which asks the ECB to support general EU economic objectives, provides an additional justification since EU States explicitly make the protection of the environment a priority. They also add that this secondary mandate could be a tiebreaker between different policies: "If faced with a choice between two monetary policy measures that have the same impact on price stability, the ECB would have to choose the one that is more in line with EU policies." 31

To defend their interpretation, these central bankers directly confront the arguments put forward by the advocates of the narrow mandate model, who are portrayed as "conservatives" because they "are concerned only about central banks' action against inflation." 32 By contrast, their opponents present fighting climate change as "an imperative that we must pursue in the very name of our current mandate and to ensure the smooth implementation of monetary policy." (ibid.)

Moreover, Schnabel ${ }^{33}$ has played a key role in the criticism of the market neutrality concept. She argues that central banks must recognize the existence of "market failures" in pricing risks related to the environmental catastrophe ("environmental externalities"). In view of these failures, she maintains that the "market neutrality" principle must be replaced with the "market efficiency" principle. Under the latter, central banks would recognize the suboptimality of a "neutral market allocation" in the presence of market failures and implement "tilting strategies", thus deviating from market neutrality, for example by incrementally removing fossil fuel companies from their asset purchase programmes. ${ }^{34}$

Finally, both Schnabel ${ }^{35}$ and Elderson ${ }^{36}$ argue that concerns over mission creep are misplaced for two reasons. First, "the risk of doing too little too late is significantly larger than the risk of central

\footnotetext{
31 Schnabel, 3 March 2021.

32 Villeroy de Galhau, 11 February 2021.

33 Schnabel, 14 June 2021.

${ }^{34}$ Importantly, the argument by Schnabel discussed in this paragraph debunks the idea held by conservative central bankers that adopting market neutrality is not a political choice and, therefore, does not require input legitimacy. In fact, asset purchases are political choices whether they are market neutral or not (Van 't Klooster \& Fontan, 2020). As we shall see in section 4, the logical next step that Schnabel fails to take is ask how the input legitimacy of central banks could be bolstered.

${ }^{35}$ Schnabel, 27 May 2021.

${ }^{36}$ Elderson, 3 June 2021.
} 
banks and supervisors overstepping their mandate." ${ }^{37}$ Second, central banks should, within their mandate, dynamically interpret their objectives in line with citizens' concerns and contemporary challenges:

The challenges central banks are facing today are fundamentally different from the ones that were relevant when they gained broad political independence. Inflation is less of a concern to many people, in large part reflecting the achievements of central banks over time. As a result, expectations towards central banks have changed. ${ }^{38}$

In sum, our discursive analysis of central bankers' speeches on the role they should play to transition to a low-carbon economy shows a contrasted landscape. On the one hand, central bankers in the Western world agree on a thin consensus view: they should pay attention to climate change when doing so helps to fulfill their mandate (prudential motives). They also agree that their room for manoeuvre is formally constrained by their mandate (including the prioritization of their price stability objective). On the other hand, central bankers' views, especially in the Eurosystem, differ radically on the substantive interpretation of their mandate when it comes to acting on climate change and, in addition, on whether their monetary policy should be informed only by prudential motives (the "conservative" view) or also by promotional motives (the "progressive" view).

\section{Ways for central banks to meet the legitimacy challenge}

Central bankers have divergent interpretations of the extent to which they can act decisively against climate change while preserving an appropriate level of input and output legitimacy. The discourse analysis in the previous section has highlighted important aspects of this divergence. Strikingly, their disagreement is focused on a topic that is not at the core of the expertise of central bankers. Rather than relating to the numerous technical questions underlying monetary policy and financial supervision - i.e., the core expertise of central bankers - the disagreement hinges on the normative question of how the mission of central banks should respond to our historically unique circumstances. On this issue, we have no reason to defer to the epistemic authority of central bankers, even if they were unanimous. Their contributions to the discussion should rather be taken

\footnotetext{
37 Idem.

${ }^{38}$ Schnabel, 27 May 2021. In a context of rising inflation in early 2022, this kind of argument rests on shaky foundations.
} 
as informed points of view and be combined with other perspectives in an effort to select reasonable options in a context characterized by fundamental uncertainty and high stakes.

We have to grant certain premises to both sides of the disagreement among central bankers. Given the climate urgency, those who maintain that central banks should promote the transition have a strong point. The threat is immense and solutions will necessarily involve departing from the status quo in many institutional settings. Yet, 'conservative' central bankers are right that independent central banks hardly have the input legitimacy today to promote the transition. From a democratic perspective, even though decisions speeding up the transition to a low-carbon economy benefit from strong output legitimacy, it is unpalatable to let unelected technocrats stretch the interpretation of their mandates to deliberately pick which economic sectors should thrive or shrink. Once these two premises are accepted, the next step is to think about ways for central banks to have sufficient input legitimacy to engage in more active climate policies.

As we have seen in section 3, central bankers themselves thus far remain silent on how to overcome their lack of input legitimacy. For example, the recent ECB announcement on its next climate strategy ${ }^{39}$ does not tackle the issue of legitimacy and coordination with other institutions. In this section, we discuss two strategies to address the legitimacy dilemma of green central banking: broadening mandates and increasing coordination. While the first tends to dominate debates on how to institutionally embed green central banking, we argue that the second strategy is actually the more promising one (see also de Boer and Van 't Klooster 2020).

A first line of reform consists in adding additional environmental objectives to central bank mandates while preserving their operational independence. For example, in March 2021, the UK government asked the Bank of England to "take into account the Government's legally binding commitment to transition to a net zero economy by $2050^{\prime \prime 40}$ and updated its mandate accordingly. The thought is that explicitly including this goal in the central bank's mandate can overcome the dilemma of legitimacy, because the institution formulating the mandate - government - provides

\footnotetext{
39 The press release is accessible at https://www.ecb.europa.eu/press/pr/date/2021/html/ecb.pr210708_1 f104919225.en.html ${ }^{40}$ See the announcement at https://www.gov.uk/government/news/climate-considerations-now-fully-embeddedacross-uk-principal-financial-regulators
} 
the input legitimacy the central bank lacks. However, on closer inspection, this is clearly not sufficient.

To take a concrete example, if central banks had a formal mandate to tilt their asset purchases in favour of green assets (incentive-based policy for promotional motives; see section 2), their discretionary decisions made on these grounds would have obvious distributive consequences and thus still fall foul of input legitimacy. One apparent solution would be to specify precisely what central banks ought to do and what they are forbidden to do in their mandates, but this option is not a feasible one. For good reasons, central bank mandates are left deliberately vague and they provide little guidance on the permissibility of specific monetary operations or on specific targets that must be reached (Van 't Klooster 2019). ${ }^{41}$ This is why democratic oversight over central bank activities is performed through accountability procedures rather than by reducing their operational discretion. In turn, accountability considerations explain why central banks tasked with multiple objectives usually benefit from a lower level of independence than single objective central banks: political authorities need more oversight over central bank activities to weigh in on the trade-offs related to the attainment of their multiple objectives (Goodhart and Meade 2004). Consequently, delegating new tasks to central banks without adjusting the mechanisms of check and balances creates democratic risks (Elgie 2002; Héritier and Lehmkuhl 2011).

Furthermore, mandate revision faces formidable feasibility constraints in the case of some central banks. For example, the ECB is often considered as the most independent central bank in the world precisely because political fragmentation and legal dispositions preclude mandate change: all 27 EU member states would need to agree on Treaty changes through referendums or preliminary approval (Quaglia 2008). Hence, changing the mandate is neither a strategy to reach a sufficient level of input legitimacy nor a feasible strategy in some cases.

A second strategy consists in building new channels of coordination between elected officials, central bankers and other actors in order to inject input legitimacy to green central banking. Such coordination was common in Western Europe during the Bretton Woods era and is still present in developing economies today (cf. section 2). For example, in post WWII France, mixed committees

${ }^{41}$ This vagueness is motivated by the so-called "Goodhart's law": when central banks are asked to reach specific targets, financial operators try to anticipate central banks' monetary policy and alter its outcome (Goodhart 1984). 
including central bankers, government representatives and private economic agents steered credit towards strategic economic sectors (Lemoine 2016; Monnet 2018). In China, central bankers have been working with financial regulators and government officials on the definition of green credit guidelines since 2007. In the context of Western independent central banks, these new channels of coordination could challenge the CBI status quo to varying degrees. For example, a mild reform to CBI consists in "comply or explain" procedures whereby central bankers would take the input of elected officials to decide which 'dirty' assets should be removed from asset purchase programmes. Alternatively, central bankers could be asked to systematically let their monetary policy decisions be informed by green public taxonomies, that is classifications of economic activities into various shades of green that are produced and updated by experts and elected representatives (Alessi et al. 2021). ${ }^{42}$ In the same vein, central banks could offer more liquidity at favorable terms to public investment banks, which would then be responsible for channeling this liquidity towards lowcarbon economic sectors. Finally, they might play a role in facilitating the issuance of long-term climate bonds designed to share the burden of the transition to a low-carbon economy between generations and to weaken the feasibility constraints on climate action (Broome and Foley 2016). ${ }^{43}$

Considering a more radical rupture from CBI, new mixed committees with representatives from the central bank and elected officials could be created to make decisions on credit allocation to low-carbon economic sectors. While boosting the input legitimacy of green central banking, these committees could have an additional benefit. By bringing more diverse perspectives to the policymaking process, the resulting higher level of epistemic diversity would make it more likely that effective error-correction mechanisms are in place when taking decisions on difficult policy trade-offs that have significant distributive consequences (see Dietsch et al. 2018: chapter 4).

Increased coordination does not imply that central bankers lose their independence from political authorities wholesale. History shows that central bank independence is not a binary issue but rather

\footnotetext{
42 One caveat here is that such taxonomies only define the criteria that economic sectors must meet to be classified as green, but they do not assess which financial assets are green or not. Hence, when central banks operationalize green monetary policy, they would have to keep an important level of discretion. As a result, fears regarding input legitimacy would persist.

${ }^{43}$ Note that these mild reforms can be implemented without changing the mandate.
} 
comes in degrees (Singleton 2010). In the case of green central banking, losing a certain degree of operational independence might be a small price to pay to secure the necessary input legitimacy. ${ }^{44}$

Increased coordination also comes with potential drawbacks that must be acknowledged. If the vested interests and worldviews of participants to mixed committees are too diverse, the decisionmaking process might be mired in political deadlock or the search for the lowest common denominator. More generally, any well-intentioned reform can backfire and lead central banks to be less effective at what they do and, consequently, less output legitimate. Ultimately, much hinges on whether we consider that the climate crisis calls for bold actions. Given that the institutional status quo leads us to a dreadful destination, reform is worth pursuing even if its outcomes are far from certain. Better to adjust our course on the way than to keep running straight toward the precipice.

\section{Conclusion}

We have argued that central banks find themselves between a rock and a hard place when it comes to green central banking. Either they endorse the project, exposing them to the charge that they lack the input legitimacy to do so, or they eschew taking into account climate concerns, thus undermining their output legitimacy.

Our analysis of central bankers' discourse has shown two things. First, representatives of the same central bank who operate under the same mandate, disagree on whether certain aspects of green central banking are a good idea. What is perhaps more worrisome, this disagreement seems grounded not so much in their expertise on monetary policy, but in issues at the periphery of their competences. Second, neither the conservative nor the progressive central bankers defend positions that have the potential to overcome the legitimacy dilemma we have formulated.

\footnotetext{
44 This holds even if it turned out that it required a sacrifice in terms of output legitimacy, for instance because attaining price stability for some reason became harder under that institutional arrangement. This is a logical consequence of accepting the tension between the two kinds of legitimacy. Note that this undermines the position of some central bankers that we should not pursue certain avenues merely because they make attaining price stability harder. All that said, it is not obvious theoretically or empirically, that boosting input legitimacy in the ways presented here actually would entail costs in terms of output legitimacy.
} 
To do so, changing a central bank's mandate is not enough. Instead, this requires coordination of various kinds between central bankers and elected officials. Be it through political input into the kind of assets they purchase, via the creation of joint committees of central bankers and members of parliament, to the collaboration with a green investment bank, the only way for central banks to overcome their lack of input legitimacy regarding policies with distributive consequences is to coordinate with those who have it. Clearly, this entails giving up some of the operational independence most Western central banks have grown used to. 


\section{References}

Alessi, L., Ossola, E., \& Panzica, R. (2021). 'What greenium matters in the stock market? The role of greenhouse gas emissions and environmental disclosures', Journal of Financial Stability, 54. DOI: $10.1016 /$ j.jfs.2021.100869

Arneson, R. J. (2003). 'Defending the Purely Instrumental Account of Democratic Legitimacy', Journal of Political Philosophy, 11/1: 122-32. DOI: 10.1111/1467-9760.00170

Baer, M., Campiglio, E., \& Deyris, J. (2021). 'It takes two to dance: Institutional dynamics and climate-related financial policies', Ecological Economics, 190: 107210. DOI:

10.1016/j.ecolecon.2021.107210

Barmes, D., \& Livingstone, Z. (2021). The Green Central Banking Scorecard: How Green Are G20 Central Banks And Financial Supervisors? Positive Money. Retrieved October 28, 2021, from <http://positivemoney.org/wp-content/uploads/2021/05/Positive-MoneyStrategy-2021-Single-final.pdf>

Boer, N. de, \& Van't Klooster, J. (2020). 'The ECB, the courts and the issue of democratic legitimacy after Weiss', Common Market Law Review, 57/6: 1689-724.

Bolton, P., Despres, M., Da Silva, L. A. P., Samama, F., \& Svartzman, R. (2020). 'The green swan', BIS Books. Bank for International Settlements.

Brennan, J. (2016). Against Democracy. Against Democracy. Princeton: Princeton University Press. DOI: $\underline{10.1515 / 9781400882939}$

Broome, J., \& Foley, D.K. (2016). 'A World Climate Bank.' Gonzalez-Ricoy I. \& Gosseries A. (eds) Institutions for Future Generations. Oxford: Oxford University Press, pp. 156-69.

Buchanan, A. (2002). 'Political Legitimacy and Democracy', Ethics, 112/4: 689-719. The University of Chicago Press. DOI: $10.1086 / 340313$

Campiglio, E., Dafermos, Y., Monnin, P., Ryan-Collins, J., Schotten, G., \& Tanaka, M. (2018). 'Climate change challenges for central banks and financial regulators', Nature Climate Change, 8/6: 462.

Dietsch, P. (2020). 'Independent Agencies, Distribution, and Legitimacy: The Case of Central Banks', American Political Science Review, letter, 114/2: 591-95.

Dietsch, P., Claveau, F., \& Fontan, C. (2018). Do Central Banks Serve The People? Future of Capitalism series. Cambridge: Polity.

Dikau, S., \& Ryan-Collins, J. (2017). Green central banking in emerging market an developing country economies. New Economics Foundation. Retrieved from <https://neweconomics.org/uploads/files/Green-Central-Banking.pdf> 
D'Orazio, P., \& Popoyan, L. (2020). Taking up the climate change challenge: a new perspective on central banking ( No. 2020/19). LEM Papers Series, LEM Papers Series. Pisa, Italy: Laboratory of Economics and Management (LEM), Sant'Anna School of Advanced Studies. Retrieved October 28, 2021, from <https://ideas.repec.org/p/ssa/lemwps/202019.html>

Downey, L. (2021). 'Delegation in Democracy: A Temporal Analysis', Journal of Political Philosophy 29/3: 305-29.

El-Erian, M. A. (2017). The only game in town: central banks, instability, and avoiding the next collapse. New York: Random House.

Elgie, R. (2002). 'The politics of the European Central Bank: principal-agent theory and the democratic deficit', Journal of European Public Policy, 9/2: 186-200. DOI: $\underline{10.1080 / 13501760110120219}$

Ferrara, F. M. (2019). 'The battle of ideas on the euro crisis: evidence from ECB inter-meeting speeches', Journal of European Public Policy, 27/10: 1463-86. DOI: 10.1080/13501763.2019.1670231

Fontan, C., Claveau, F., \& Dietsch, P. (2016). 'Central banking and inequalities: Taking off the blinders', Politics, Philosophy \& Economics, 15/4: 319-57.

Goodhart, C. A. E. (1984). 'Problems of Monetary Management: The UK Experience'. Monetary Theory and Practice, pp. 91-121. Palgrave: London. DOI: 10.1007/978-1-349-17295-5_4

Goodhart, C., \& Meade, E. (2004). 'Central banks and supreme courts', Moneda y Crédito, 218: $11-42$.

Héritier, A., \& Lehmkuhl, D. (2011a). 'Governing in the Shadow of Hierarchy New Modes of Governance in Regulation'. Héritier A. \& Rhodes M. (eds) New Modes of Governance in Europe: Governing in the Shadow of Hierarchy, Palgrave Studies in European Union Politics, pp. 48-74. Palgrave Macmillan UK: London. DOI: $10.1057 / 97802303064553$

Héritier, A., \& Lehmkuhl, D. (2011b). 'New modes of governance and democratic accountability', Government and Opposition, 46/1: 126-44.

Hockett, R., \& James, A. (2020). Money from nothing: or, why we should learn to stop worrying about debt and love the Federal Reserve. Brooklyn, NY: Melville House.

Ingham, G. K. (2004). The nature of money. Cambridge, UK ; Malden, MA: Polity.

Ingham, G. K. (2020). Money. What is political economy? Cambridge, UK ; Medford, MA: Polity.

Issing, O., Gaspar, V., Angeloni, I., \& Tristani, O. (2001). Monetary Policy in the Euro Area: Strategy and Decision-Making at the European Central Bank. Cambridge: Cambridge University Press. 
Lemoine, B. (2016). L'ordre de la dette: Enquête sur les infortunes de l'État et la prospérité du marché. Paris: La Découverte.

Majone, G. (Ed.). (1996). Regulating Europe. European public policy series. London ; New York: Routledge.

Monnet, E. (2018). Controlling Credit: Central Banking and the Planned Economy in Postwar France, 1948 1973. Cambridge University Press.

Monnin, P. (2018). Central banks should reflect climate risks in monetary policy operations (SUERF Policy Note No. No 41)., p. 9. The European Money and Finance Forum.

NGFS Secretariat/Banque de France. (2019). A sustainable and responsible investment guide for central banks' portfolio management (NGFS Technical document)., p. 41. Network for Greening the Financial System.

OECD. (2002). Distributed Public Governance: Agencies, Authorities and other Government Bodies. Paris: Organisation for Economic Co-operation and Development.

Peter, F. (2009). Democratic legitimacy. Routledge studies in social and political thought. New York: Routledge.

Peter, F.. (2017). 'Political Legitimacy'. (E. N. Zalta, Ed.)Stanford Encyclopedia of Philosophy.

Quaglia, L. (2008). Central banking governance in the European Union: a comparative analysis. London: Routledge.

Scharpf, F. W. (1997). 'Economic integration, democracy and the welfare state', Journal of European Public Policy, 4/1: 18-36.

Singleton, J. (2010). Central Banking in the Twentieth Century. Cambridge: Cambridge University Press.

Steffek, J. (2019). "The limits of proceduralism : Critical remarks on the rise of 'throughput legitimacy"'. Public Administration, 97/4: 784-796.

Van't Klooster, J. (2020). 'The ethics of delegating monetary policy', The Journal of Politics, 82/2: 587-99. The University of Chicago Press Chicago, IL.

Van't Klooster, J., \& Fontan, C. (2020). 'The myth of market neutrality: A comparative study of the European Central Bank's and the Swiss National Bank's corporate security purchases', New political economy, 25/6: 865-79.

Viehoff, D. (n.d.). Challenging Democratic Commitments: On Liberal Arguments for Instrumentalism about Democracy. Manuscript.

Volz, U. (2017). 'On the role of central banks in enhancing green finance',. UN environment inquiry working paper 17/01. 


\section{Appendix I: Cited documents from our corpus}

Bailey, Andrew (Bank of England), 1 June 2021, "Tackling climate for real - the role of central banks", at Reuters Events Responsible Business. https://www.bis.org/review/r210602a.htm

Boediono (Bank of Indonesia), 1-2 August 2008, "Macroeconomic impact of climate change opportunities and challenges (Keynote speech)", at Bank Indonesia's Annual International Seminar on 'Macroeconomic impact of climate change - opportunities and challenges', Nusa Dua, Bali. https://www.bis.org/review/r080901c.htm

Brainard, Lael (Federal Reserve System), 8 November 2019, "The Economics of Climate Change", a research conference sponsored by the Federal Reserve Bank of San Francisco, San Francisco, California. https://www.bis.org/review/r191111a.htm

Carney, Mark (Bank of England), 29 September 2015, "Breaking the tragedy of the horizon climate change and financial stability", Lloyd's of London, London, United Kingdom. https://www.bis.org/review/r151009a.htm

Cœuré, Benoît (European Central Bank), 8 November 2018, "Monetary policy and climate change", at a conference on "Scaling up Green Finance: The Role of Central Banks", organised by the Network for Greening the Financial System, the Deutsche Bundesbank and the Council on Economic Policies, Berlin. https://www.bis.org/review/r181109f.htm

Donnery, Sharon (Bank of Ireland), 31 January 2020, "Central banks and public policy - stability in an interconnected world", at the Warwick Economics Summit, Warwick. https://www.bis.org/review/r200203i.htm

Elderson, Frank (European Central Bank), 3 June 2021, "The embrace of the horizon - forcefully moving with the changing tide for climate action in financial sector policies", at the Green Swan 2021 Global Virtual Conference. https://www.bis.org/review/r210604c.htm

Lane, Timothy (Bank of Canada), 2 March 2017, "Thermometer rising - climate change and Canada's economic future", at the Finance and Sustainability Initiative, Montréal, Québec. https://www.bis.org/review/r170405b.htm

Lautenschläger, Sabine (European Central Bank), 30 October 2019, "A call for Europe", at lecture series "Mein Europa", Heinrich-Heine University, Düsseldorf. https://www.bis.org/review/r191031b.htm

Maechler, Andréa M. (Swiss National Bank) and Thomas Moser (Swiss National Bank), 14 November 2019, "Climate risks and central banks - an SNB perspective", at the Money Market Event, Geneva. https://www.bis.org/review/r191115a.htm

Mersch, Yves (European Central Bank), 27 November 2018. "Climate change and central banking", at the Workshop discussion "Sustainability is becoming mainstream", Frankfurt am Main, Germany. https://www.bis.org/review/r181128b.htm 
Nykänen, Marja (Bank of Finland), 21 May 2021, "Maintaining the EU as global leader in sustainable finance", at the European SSM Round Table, digital conference. https://www.bis.org/review/r210521b.htm

Schabel, Isabel (European Central Bank), 14 June 2021, "From market neutrality to market efficiency", at the ECB DG-Research Symposium "Climate change, financial markets and green growth", Frankfurt am Main. https://www.bis.org/review/r210614a.htm

Schnabel, Isabel (European Central Bank), 27 May 2021, "Societal responsibility and central bank independence", at the "VIII. New Paradigm Workshop", organised by the Forum New Economy, Frankfurt am Main. https://www.bis.org/review/r210528e.htm

Schnabel, Isabel (European Central Bank), 3 March 2021, "From green neglect to green dominance?", at the "Greening Monetary Policy - Central Banking and Climate Change" online seminar, organised as part of the "Cleveland Fed Conversations on Central Banking", Frankfurt am Main. https://www.bis.org/review/r210304c.htm

Trichet, Jean-Claude (European Central Bank), 3 June 2008, "Monetary policy in challenging times", Barcelona, Spain.

https://www.ecb.europa.eu/press/key/date/2008/html/sp080603.en.html

Villeroy de Galhau, François (Bank of France), 11 February 2021, "The role of central banks in the greening of the economy",at the 5th edition of the Rencontres on "Climate Change and Sustainable Finance", organised jointly with Option Finance. Paris. https://www.bis.org/review/r210211g.htm

Weidmann, Jens (Deutsche Bundesbank), 1 July 2021, "Monetary policy and the role of central banks - an outlook", to the Freundeskreis of the Ludwig-Erhard-Stiftung, virtual speech. https://www.bis.org/review/r210809b.htm

Weidmann, Jens (Deutsche Bundesbank), 29 October 2019, "Climate change and central banks", at the Deutsche Bundesbank's second financial market conference, Frankfurt am Main. https://www.bis.org/review/r191029a.htm

Weidmann, Jens (Deutsche Bundesbank), 3 February 2020, "Change and continuity", at Deutsche Börse's New Year's reception, Eschborn. https://www.bis.org/review/r200204b.htm 